\title{
Understanding Idiopathic Interstitial Pneumonia: A Gene-Based Review of Stressed Lungs
}

\author{
Coline H. M. van Moorsel, ${ }^{1,2}$ Thijs W. Hoffman, ${ }^{1}$ Aernoud A. van Batenburg, ${ }^{1}$ Dymph Klay, \\ Joanne J. van der Vis, ${ }^{1,3}$ and Jan C. Grutters ${ }^{1,2}$ \\ ${ }^{1}$ Center for Interstitial Lung Disease, Department of Pulmonology, St. Antonius Hospital, \\ P.O. Box 2500, 3430 EM Nieuwegein, Netherlands \\ ${ }^{2}$ Division of Heart and Lung, University Medical Center Utrecht, P.O. Box 85500, 3508 GA Utrecht, Netherlands \\ ${ }^{3}$ Center for Interstitial Lung Disease, Department of Clinical Chemistry, St. Antonius Hospital, \\ P.O. Box 2500, 3430 EM Nieuwegein, Netherlands
}

Correspondence should be addressed to Coline H. M. van Moorsel; c.van.moorsel@antoniusziekenhuis.nl

Received 19 June 2015; Accepted 26 August 2015

Academic Editor: Shinichiro Ohshimo

Copyright (C) 2015 Coline H. M. van Moorsel et al. This is an open access article distributed under the Creative Commons Attribution License, which permits unrestricted use, distribution, and reproduction in any medium, provided the original work is properly cited.

\begin{abstract}
Pulmonary fibrosis is the main cause of severe morbidity and mortality in idiopathic interstitial pneumonias (IIP). In the past years, there has been major progress in the discovery of genetic factors that contribute to disease. Genes with highly penetrant mutations or strongly predisposing common risk alleles have been identified in familial and sporadic IIP. This review summarizes genes harbouring causative rare mutations and replicated common predisposing alleles. To date, rare mutations in nine different genes and five risk alleles fulfil this criterion. Mutated genes represent three genes involved in surfactant homeostasis and six genes involved in telomere maintenance. We summarize gene function, gene expressing cells, and pathological consequences of genetic alterations associated with disease. Consequences of the genetic alteration include dysfunctional surfactant processing, ER stress, immune dysregulation, and maintenance of telomere length. Biological evidence shows that these processes point towards a central role for alveolar epithelial type II cell dysfunction. However, tabulation also shows that function and consequence of most common risk alleles are not known. Most importantly, the predisposition of the MUC5B risk allele to disease is not understood. We propose a mechanism whereby MUC5B decreases surface tension lowering capacity of alveolar surfactant at areas with maximal mechanical stress.
\end{abstract}

\section{Idiopathic Interstitial Pneumonia}

Idiopathic interstitial pneumonias (IIP) are a class of diffuse lung diseases comprising several distinct entities. Idiopathic pulmonary fibrosis (IPF) is the most common and severe form of IIP. Median survival in IPF is 3 years [1]. Other less common entities include nonspecific interstitial pneumonia (NSIP), desquamative interstitial pneumonitis (DIP), and cryptogenic organizing pneumonia (COP). Distinction between the different entities of IIP is important with regard to prognosis and therapeutic decision-making, including timing of lung transplantation or palliative care. However, genetic discoveries have raised the question whether the various types of IIP are in fact different disease manifestations within the same pathogenetic spectrum [2]. In a large cohort of patients with familial interstitial pneumonia (FIP), it was found that a diagnosis of IPF was most frequent, but all subtypes of IIP were represented [3]. Furthermore, although it is commonly assumed that IPF does not and non-IPF IIP does respond to immunosuppressive treatment, part of the non-IPF IIP patient population are refractory to treatment and progress to end-stage fibrosis with severely reduced survival [4].

\section{Familial Disease}

All human phenotypes, including disease phenotypes, are influenced by a person's genetic constitution. In case of IIP, evidence for a more defining genetic contribution to disease is most compelling. Ethnic differences in incidence of IPF 
include higher occurrence in Hispanics than in Whites and the lowest occurrence in Blacks and Maori $[5,6]$. In theory, familial occurrence may well be explained by presence of a common environmental cause. An environmental cause requires clustering of affected family members in space and time, while a genetic cause allows for differences in space and time. Such differences are frequently observed in familial IIP including sibs from different environments and parent-offspring disease with an interval of decades [3, 79] and support the involvement of heritable factors. IIP is familial in approximately $10 \%$ of cases [10] and might even reach $20 \%$ in cohorts with IPF or end-stage lung disease $[11,12]$. These numbers may even be an underestimation, because the studies relied on patient reports. With more elaborate measurement of familial disease, an even larger familial component can be identified. Scholand and coworkers performed an extraordinary study for which they first identified 1,000 cases that died from pulmonary fibrosis in the Utah Population Database. They showed that the average relatedness of these 1,000 cases was significantly higher than that of matched controls even when first- and second-degree relatives were excluded [13].

\section{Alveolar Epithelial Type II Cell}

A major breakthrough was achieved when the first causative mutation was identified in a family with IIP. Candidate gene sequencing detected a heterozygous mutation in surfactant protein C (SFTPC) [14]. Because SFTPC is exclusively expressed in type II alveolar epithelial cells (AECs), it was proof that erroneous processes in AEC type II could ultimately lead to pulmonary fibrosis.

The reported family already contained many features of disease associated with SFTPC mutations: familial ILD, dominant expression, variable penetrance, and expressivity resulting in acute and chronic lung disease in individuals ranging from newborn to adult $[10,15,16]$. Since the first discovery, many IIP families with surfactant mutations have now been described. SFTPC mutations are now established as an important cause of paediatric ILD but also known to contribute to, predominantly familial, IIP in adults $[10,17-$ 19]. Table 1 summarizes characteristics of mutated genes in IIP and biological consequences of mutations.

\section{Surfactant Processing}

After transcription and translation of SFTPC in AEC type II, a proprotein is formed which after subsequent folding and cleavage steps becomes a mature surfactant protein ready for secretion into the alveolar space via lamellar bodies. Pulmonary surfactant consists of a mixture of lipids and specific proteins that lowers alveolar surface tension thereby preventing alveolar collapse at the end of expiration $[20,21]$.

Erroneous SFTPC processing is currently one of the best studied mechanisms leading to IIP. The consequence of a mutation in SFTPC depends on its position in the gene [22].

Mutations in the C-terminal BRICHOS domain generally increase endoplasmic reticulum (ER) stress and activate the unfolded protein response (UPR) in AEC type II [23-26].
In turn, ER stress can induce epithelial-to-mesenchymal transition in lung epithelial cells [24].

The role of ER stress is not limited to SFTPC mutation carriers, as different studies showed that AECs in fibrotic tissue from nonmutated FIP and sporadic IPF patients were also positive for ER-stress markers [23, 27].

The most common SFTPC mutation is I73T and does not cause substantial elevation of ER stress [28]. It represents a linker domain mutation that alters trafficking of the propeptide to early endosomes [29] and causes dysregulated proteostasis [30]. Furthermore, alteration of the surfactant lipid composition and activation of immune cells are reported for these mutations [31].

Later, mutations in a second surfactant associated gene, surfactant protein A2 (SFTPA2), were identified in two families. Family members presented with adult early-onset pulmonary fibrosis or lung cancer with features of bronchioloalveolar carcinoma [32]. Surfactant protein A2 is a C-type lectin important in the defense against respiratory pathogens and in the lung. It is expressed not only by AEC type II, but also by Clara cells and submucosal glands [33, 34]. The mutant protein, when expressed in AECs, was not excreted but retained in the ER and induced ER stress [35], a process similar to that seen in SFTPC mutants. However, there are no reports on lung cancer in patients with SFTPC mutation. ER stress is linked to tumorigenesis [36] and tumorigenesis in BAC is often thought to involve Clara cells [37].

\section{Lamellar Bodies}

Lamellar bodies are secretory organelles unique to type II AEC and are crucial for biosynthetic processing and transport of pulmonary surfactant. Proteins of the limiting membrane of lamellar bodies are encoded by the gene $A B C A 3$. In the lung, the highest expression of $A B C A 3$ has been observed in type II AEC and corresponds with the presence of lamellar bodies [20]. Recessive mutations in $A B C A 3$ are the most common genetic cause of lethal surfactant deficiency in neonates or chronic ILD in children [38-40].

In type II AECs, $A B C A 3$ mutations cause abnormal processing, trafficking, and functionality of the ABCA3 protein $[41,42]$, resulting in impaired lipid transport [43] or retention in the ER compartment and elevated ER stress and apoptotic signaling [44]. Only recently were compound heterozygous or homozygous mutations in $A B C A 3$ described in adult IIP $[45,46]$. A French patient with $A B C A 3$ mutations presented with combined pulmonary fibrosis and emphysema (CPFE) [46]. CPFE typically occurs in male smokers but also has similarities to radiographs of IIP patients with SFTPC mutations [47]. Dysfunctional lamellar bodies in AEC type II were also identified as a cause of pulmonary fibrosis in HermanskyPudlak Syndrome (HPS).

HPS is a systemic disorder characterized by reduced pigmentation of skin, hair, and eyes and bleeding diathesis. Disease is caused by autosomal recessive mutations in the gene HPS1 [48] that lead to giant lamellar bodies in type II AECs with a deficiency to fuse with the outer cell membrane and excrete lamellar body content [49-51]. Pulmonary fibrosis in HPS shares many similarities with that observed in IPF 


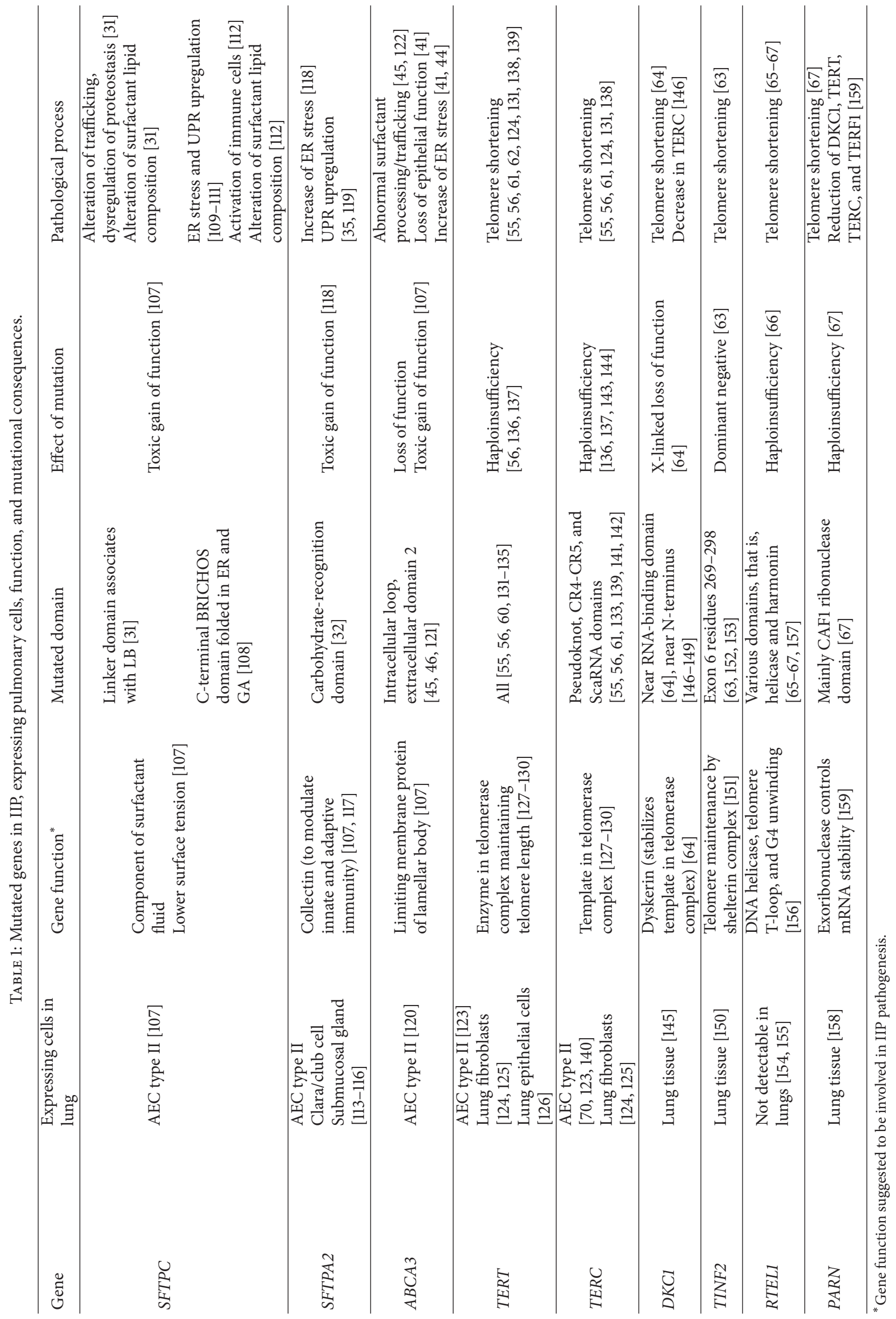


$[52,53]$. Due to unfamiliarity with the disease and the variable degree of albinism and bleeding disorders misdiagnosis might occur. However, clinical features characteristic for HPS are scars in pulmonary fibrosis. In a cohort study including 127 patients with pulmonary fibrosis, only four patients had two or more features consistent with HPS. One out of four had HPS and was compound heterozygous for mutations in HPS1. Review of her medical documentation showed that she had received a diagnosis of IPF prior to referral to a tertiary center [54].

\section{Telomere Maintenance}

A different set of genes involved in FIP was discovered when anamnestic familial [55] and genome-wide linkage [56] analysis linked IIP to mutations in the genes TERT and TERC. The gene TERT encodes telomerase reverse transcriptase, which together with the transcript of the telomerase RNA component (TERC) forms the telomere complex, required to maintain telomere length.

Mutations in the telomerase genes have been found to cause a telomere syndrome with one or more manifestations of early aging, such as idiopathic pulmonary fibrosis, bone marrow failure, or cryptogenic liver cirrhosis [57]. A mutation in one TERT allele can lead to haploinsufficiency that results in overall decreased telomerase activity and is manifested as premature aging disorders. Approximately half of the mutations (10 out of 19) have less than $40 \%$ loss of telomerase function. In a heterozygous individual carrying one wild type and one mutant allele, this would result in "normal," > $80 \%$, overall telomerase activity [58]. However, carriers of mutations that cause a minor decrease in overall telomerase activity were shown to cause significant reduction of telomere length over generations that will eventually lead to telomere syndromes $[55,56,59]$. It is not the presence of the mutation per se but the length of telomeres that confers the risk for disease. Because telomere length is heritable, carriage of slightly dysfunctional alleles will over generations lead to pathologically short telomeres, a phenomenon known as genetic anticipation.

Leukocytes telomere lengths in cohorts of FIP and sporadic IIP patients were significantly shorter compared to age-matched controls [60, 61]. Although this is interesting, acquired telomere shortening is a common feature of disease in humans and, recently, it was shown that all ILD patient cohorts have shorter telomere length than controls. However, patients with sporadic IPF had significantly shorter telomeres than patients with other forms of IIP or patients with surfactant mutations [62]. This suggests that telomere shortening is a common denominator of patients with ILD but telomere dysfunction is only key to IPF.

\section{Alveolar Epithelial Type II Cell Senescence}

Although telomerase has much more functions than maintenance of telomere length, these are not suggested to play a major role in the pathogenesis of IIP. The prominent role of telomere length instead of telomerase is underlined by the observed genetic anticipation in congruence with development of disease phenotypes. Furthermore, recently, another four genes, TINF2, DKC1, RTEL1, and PARN, involved in telomere maintenance have been discovered to harbor mutations associated with IIP [63-67]. Altogether, this points towards maintenance of telomere length as the unifying cause and not the secondary functions of the individual genes.

AECs type II are responsible for growth, differentiation, and repair in alveoli [68]. In case of alveolar injury AEC type II cells proliferate along the alveolar basement membrane and differentiate in AEC type I [69].

Recently, it was shown that critically short telomeres in AEC type II preferentially induce cellular senescence [70]. Such cell cycle alterations are mediated by p53 and p21. Increased levels of p53 and p21 have been observed in hyperplastic AECs in IPF patients [71] and polymorphisms in these genes were shown to associate with disease development in IPF [72]. Cellular senescence of type II AEC caused regenerative defects, inflammatory responses, and susceptibility to injury in mice lungs and mice lung organoids [70]. This strongly implicates type II AEC senescence as a causative mechanism in IIP pathogenesis.

\section{Common Risk Alleles}

At the outset of genetic studies at the end of the last century, pulmonary fibrosis was thought to result from a chronic inflammatory process. It was therefore logical that cytokine genes were among the first candidate genes studied [73]. Only one gene from that period, interleukin-1 receptor antagonist (IL1RN), the gene encoding interleukin-1 receptor antagonist (IL-1Ra), now fulfills our criterion of independent replication, although both positive and negative associations have been published [74-77]. A meta-analysis including all five cohorts showed that carriage of ILIRN VNTR*2 predisposed to IPF with an odds ratio of 1.6 [78]. The risk allele associates with a reduction of the IL-1Ra to IL- $1 \beta$ ratio and thereby causes a profibrotic environment. In vivo this effect can be counteracted with addition of IL-1Ra, which was shown to prevent fibrogenesis in mice with bleomycin induced fibrosis [79]. Mutations in IL1RN cause deficiency in IL-1Ra which result in systemic life-threatening neonatal autoinflammatory disease [80]. Local deviations of desired IL-1Ra levels might be associated with the autoinflammatory environment that is seen in IPF lung and is not responsive to immunosuppressive therapy. Immunosuppressive therapy suppresses IL-1Ra synthesis [81] and has been shown to be harmful in IPF [82]. All other evidence for the involvement of common genetic variants in IIP is the result of hypothesisfree genome-wide studies. The common genetic variants that have been associated with IIP in multiple independent cohorts are shown in Table 2.

\section{Genome-Wide Studies}

Genome-wide linkage and fine-mapping identified the minor allele of rs35705950 to be associated with disease in both FIP and IPF. rs35705950 is situated in the putative promoter of $M U C 5 B$ and the risk allele was shown to correlate with 
TABLE 2: Genes with polymorphisms predisposing to IIP in multiple studies, expressing pulmonary cells, function, and mutational consequences.

\begin{tabular}{|c|c|c|c|c|c|}
\hline Gene & $\begin{array}{l}\text { Expressing cells in } \\
\text { lung }\end{array}$ & Gene function & Risk allele & $\begin{array}{l}\text { Effect of risk } \\
\text { allele }\end{array}$ & Cellular consequence \\
\hline$I L 1 R N$ & $\begin{array}{l}\text { Bronchus epithelium } \\
{[160]} \\
\text { Alveolar epithelium } \\
\text { [161] } \\
\text { Immune cells [162] }\end{array}$ & $\begin{array}{l}\text { Inhibitor of } \\
\text { proinflammatory } \\
\text { effect of IL- } 1 \alpha \text { and } \\
\text { IL-1 } \beta[163]\end{array}$ & $\begin{array}{l}\text { VNTR }^{*} 2 \text { haploblock } \\
{[78]^{\#}}\end{array}$ & $\begin{array}{l}\text { Decreased } \\
\text { expression [78] }\end{array}$ & $\begin{array}{l}\text { Increase of } \\
\text { IL-1 } \beta / \text { Il-1Ra ratio } \\
\text { with proinflamma- } \\
\text { tory/fibrotic effect } \\
{[74]}\end{array}$ \\
\hline TERT & $\begin{array}{l}\text { AEC type II [123] } \\
\text { Lung fibroblasts [124] } \\
\text { Lung epithelial cells } \\
{[126]}\end{array}$ & $\begin{array}{l}\text { Enzyme in telomerase } \\
\text { complex maintaining } \\
\text { telomere length } \\
{[127-130]}\end{array}$ & $\begin{array}{l}\text { rs2736100 major A } \\
\text { allele }[86,97,98,164]\end{array}$ & $?$ & $?$ \\
\hline$M U C 5 B$ & $\begin{array}{l}\text { Airway submucosal } \\
\text { glands [165] } \\
\text { Macrophages [166] }\end{array}$ & $\begin{array}{l}\text { Influence on } \\
\text { rheological properties } \\
\text { of airway mucus, } \\
\text { mucociliary } \\
\text { transport, and airway } \\
\text { defense }[93,165]\end{array}$ & $\begin{array}{l}\text { rs35705950 minor T } \\
\text { allele } \\
{[83,84,86,87,96,98 \text {, }} \\
100,164,167-169]\end{array}$ & $\begin{array}{l}\text { Expression } \uparrow \\
{[83]}\end{array}$ & $\begin{array}{l}\text { Lower bacterial } \\
\text { burden }[93,94] \\
\text { Improved } \\
\text { macrophage function } \\
{[93]}\end{array}$ \\
\hline$L R R C 34$ & $\begin{array}{l}\text { Not detected in } \\
\text { human lung [170] }\end{array}$ & $x_{1}$ & $\begin{array}{l}\text { rs6793295 minor C } \\
\text { allele }[86,98]\end{array}$ & $?$ & $?$ \\
\hline FAM13A & Lung tissue [99] & $?$ & $\begin{array}{l}\text { rs2609255 minor G } \\
\text { allele }[86,98]\end{array}$ & $\begin{array}{l}\text { ? } \\
\text { No upregulation } \\
\text { in lung tissue } \\
{[98]}\end{array}$ & $?$ \\
\hline$I V D$ & $?$ & $\begin{array}{l}\text { Mitochondrial matrix } \\
\text { enzyme involved in } \\
\text { leucine catabolism } \\
\text { [98] }\end{array}$ & $\begin{array}{l}\text { rs2034650 major } \mathrm{T} \\
\text { allele }[86,98]\end{array}$ & $\begin{array}{l}? \\
\text { No upregulation } \\
\text { in lung tissue } \\
{[98]}\end{array}$ & $?$ \\
\hline
\end{tabular}

\#Pooled meta-analysis of five independent cohorts [74-77].

increased $M U C 5 B$ expression in lung from unaffected subjects [83]. Carriage of the risk allele conferred high odds ratios well over five [83, 84]. Such high odds ratios in genome-wide analyses are seldom found and would usually involve rare variants [85]. However, the minor allele of rs 35705950 is not rare in Caucasian cohorts where the population frequency is approximately $10 \%$.

In African Yoruban, African American, and Asian populations, risk allele frequencies are rare and vary between 0 and 3\% (http://www.ncbi.nlm.nih.gov/projects/SNP/snp_ref .cgi? $r s=35705950)$. The contribution to disease of the risk allele in these cohorts is still under investigation [86, 87]. Interestingly, the SNP was recently shown to be associated not only with IPF, but also with NSIP in a small German cohort, which suggests that IPF and NSIP have similar pathogenesis with regard to MUC5B [87].

\section{Airway Involvement}

In the lung, MUC5B is preferentially expressed by distal airway epithelium, but not by alveolar epithelium [88]. Several exogenous factors, including cigarette smoke, and endogenous factors have been shown to increase MUC5B expression or decrease clearance in the lung $[50,89,90]$. Chronic airway diseases are commonly accompanied by raised expression of gel-forming mucins. Interestingly, in human bronchial cells it was shown that proinflammatory cytokines IL-1 $\beta$ and IL-17A were potent inducers of MUC5B mRNA expression. The induction by IL-1B was both time and dose dependent and involved IL-1R1 receptor binding followed by NF- $\kappa$ B-based transcriptional mechanism [91].

The MUC5B protein is present in IPF lesions and IPF patients had significantly increased expression of MUC5B in the lungs compared with controls. Changes in MUC5B levels have been suggested to interfere in alveolar repair in IPF, but this needs further investigation [83, 92]. More evidence is available regarding MUC5B dependent changes in pulmonary immune regulation. $M u c 5 b$ deficient mice have impaired mucociliary clearance. And absence of Muc5b caused accumulation of apoptotic macrophages, impaired phagocytosis, and chronic infection. Muc5b overexpression in mice leads to improved macrophage function [93]. In IPF patients carrying the risk allele a lower bacterial burden was found, suggesting a direct relationship between host immunity and bacterial load [94]. This beneficiary effect of the risk allele corresponds well with significant associations with improved survival in IPF [95], less severe pathological changes in FIP [92], and slower decline in FVC for IPF [96]. All evidence so far points towards a beneficiary effect of the risk allele during disease but its role in disease susceptibility remains elusive. 


\section{Genome-Wide Association Studies}

The first common variant that was associated with IIP through a genome-wide association study (GWAS) was rs2736100 in the TERT gene [97] in a Japanese population. The association was replicated in a second GWAS including non-Hispanic white IIP patients [98] and in a Mexican candidate gene study [86]. Furthermore, three novel IIP-associated loci that were identified in the second GWAS were also replicated in the Mexican study: polymorphisms rs6793295 (LRRC34), rs2609255 (FAM13A), and rs2034650 (IVD) (Table 2) [86]. The IVD variant was also associated with IPF in a Korean IPF population [86]. For all variants, allele frequencies differed significantly between populations, but the allele associated with increased risk for IIP was consistent.

LRRC34 is of unknown function, but the LRRC34 gene is located near the TERC gene [98], perhaps indicating an association with telomere maintenance. Polymorphisms in the FAM13A gene have been associated with lung function in the general population, as well as with various lung diseases. The function of FAM13A is unknown, but it is speculated that FAM13A polymorphisms affect rho GTPases activity, possibly affecting the lung endothelial barrier [99]. The IVD gene encodes a mitochondrial matrix enzyme involved in leucine metabolism [98]. Why an IVD polymorphism is associated with IIP remains to be determined.

One further large GWAS conducted by Noth and coworkers [100] included IPF patients and controls, distributed over three stages. There might have been a partial overlay between cases from this GWAS and the previously mentioned GWAS by Fingerlin et al. [98], as a proportion of patients were recruited from the same cohorts. This study did not identify new risk alleles that have been replicated independently.

\section{Genome Region 11 p15.5}

The GWAS by Noth et al. [100] identified three polymorphisms in the TOLLIP gene that were significantly associated with IPF. TOLLIP is a negative regulator of the TGF-beta pathway and interacts with Toll-like receptors and with interleukin-1 receptor trafficking, which makes it an interesting candidate gene for IPF susceptibility [100]. However, the association with TOLLIP has not been replicated independently. In the GWAS by Fingerlin et al. [98] associated TOLLIP SNPs had also been identified, but they discovered that the effect disappeared after correction for the effect of $M U C 5 B$. This suggests that there is linkage disequilibrium (LD) between TOLLIP and MUC5B. Both genes are located in the same chromosomal region, 11p15.5, just $12 \mathrm{~kb}$ apart (http://www.ncbi.nlm.nih.gov/gene/). Genes separated by $12 \mathrm{~kb}$ are considered to be in very close proximity, because the expected extension of LD in humans of European origin is at least $60 \mathrm{~kb}$ [101]. Measures for LD describe the nonrandom association of genetic markers based on the frequencies of the marker alleles. LD is often represented as the correlation coefficient $r^{2}$ between markers. In the study by Noth et al., $r^{2}$ between TOLLIP and MUC5B SNPs was found to be very low, $r^{2}<0.16$, and analysis of TOLLIP was therefore pursued [100]. However, another measurement for linkage disequilibrium, $D^{\prime}$, provides information about the recombination breakpoints of chromosomes. SNPs with low $r^{2}$ values can reside in a linkage disequilibrium block with a high level of $D^{\prime}$ between markers. In such a case disease associations are not independent [102]. Further studies are therefore needed to fully understand the contribution of the 11 15.5 region to disease.

\section{Genes in Disease Pathogenesis}

Genetic variations in surfactant associated genes SFTPC, SFTPA2, and ABCA3 point out AEC type II dysfunction at the initiation of disease. Coping with additional epithelial damage requires proliferation of AEC type II with proper telomere maintenance controlled by TERT, TERC, DKC1, TINF2, RTEL1, and PARN. In families, one mutation that alters the quality or quantity of any of these genes is enough to cause pulmonary fibrosis. In sporadic patients, more subtle effects of a polymorphism in TERT might steer damage control into a similar direction, although this would likely require additional damaging environmental or genetic influences. On the other hand, it is more difficult to place the MUC5B association into this model of disease pathogenesis. Verified effects of the polymorphism, such as increased production that enhances the immunological properties of the lung, associate well with the observed beneficial consequences of carriership in patients, such as increased survival and slower decline of lung function. However, it does not explain the disease predisposing effect.

\section{A Unifying Theory: MUC5B Alters Alveolar Surfactant Fluid Properties at Areas with Maximal Mechanical Stress}

Interestingly, the $M U C 5 B$ risk allele associated with the presence of interstitial lung abnormalities on HRCT in a general population. The association was independent of smoking history and stronger in a subgroup with CT evidence of fibrosis and in older participants [103]. This suggests a general role for MUC5B in induction of CT patterns of interstitial pneumonia. Such a general observation is likely to be caused by a mechanism that is uniformly present in the human lung. This mechanism might already be identified. Mechanical stress due to respiratory lung movements has been proposed to contribute to IPF and induce such CT patterns [104].

Mathematical modelling showed that the distribution of IPF lesions on HRCT coincides with the hypothetical distribution of maximal mechanical stress [105]. We postulate that, in lung, where $M U C 5 B$ is abundantly expressed, increased admixture of airway fluid to alveolar surfactant fluid might occur, thereby increasing MUC5B levels in surfactant fluid. The high MUC5B levels in the surfactant fluid might cause a significant change in its surface tension lowering capacity. Optimal surfactant reduces the surface tension by a factor of about 15 [106], which is necessary for proper alveolar size regulation during inspiration and expiration. We hypothesize that a suboptimal surfactant mix is most abundant and detrimental at areas with maximal mechanical stress as 


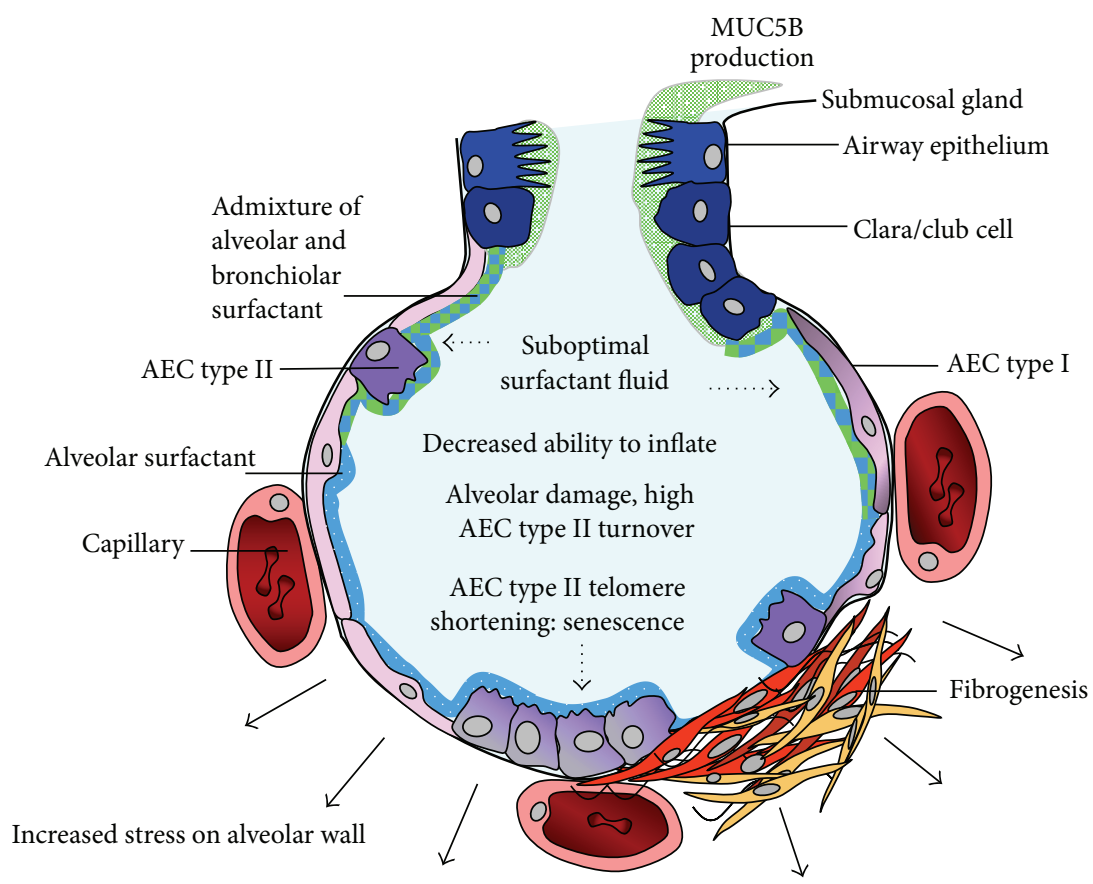

FIGURE 1: Hypothesized scheme of increased mechanical stress in MUC5B risk allele carriers. At areas with maximal mechanical stress in the lung, optimal surface tension lowering capacity of alveolar surfactant fluid is required. Through breathing mechanics admixture of alveolar and airway surfactant occurs. Increased amounts of MUC5B protein in MUC5B risk allele carriers have detrimental effect on surface tension lowering capacity of the alveolar surfactant fluid. In case of suboptimal surfactant, inflation requires increased traction on the alveolar wall and induces epithelial damage. Alveolar repair causes high epithelial cell turnover with consequent critical shortening of telomeres, which in turn induce senescence of alveolar epithelial type II cells.

the surface tension lowering capacity of alveolar surfactant fluid is most important in these areas. Increased mechanical stress causes alveolar damage that will initially be repaired by AEC type II. Increased turnover of AEC type II is associated with decreased telomere length which in turn will lead to AEC type II senescence (Figure 1). Further experiments are necessary to confirm this hypothesis.

\section{Conflict of Interests}

The authors declare that there is no conflict of interests regarding the publication of this paper.

\section{References}

[1] G. Raghu, H. R. Collard, J. J. Egan et al., "An official ATS/ERS/JRS/ALAT statement: idiopathic pulmonary fibrosis: evidence-based guidelines for diagnosis and management," American Journal of Respiratory and Critical Care Medicine, vol. 183, no. 6, pp. 788-824, 2011.

[2] T. M. Maher, A. U. Wells, and G. J. Laurent, "Idiopathic pulmonary fibrosis: multiple causes and multiple mechanisms?" European Respiratory Journal, vol. 30, no. 5, pp. 835-839, 2007.

[3] M. P. Steele, M. C. Speer, J. E. Loyd et al., "Clinical and pathologic features of familial interstitial pneumonia," American Journal of Respiratory and Critical Care Medicine, vol. 172, no. 9, pp. 1146-1152, 2005.

[4] W. D. Travis, U. Costabel, D. M. Hansell et al., "An official American Thoracic Society/European Respiratory Society statement: update of the international multidisciplinary classification of the idiopathic interstitial pneumonias," American Journal of Respiratory and Critical Care Medicine, vol. 188, no. 6, pp. 733748, 2013.

[5] J. J. Swigris, A. L. Olson, T. J. Huie et al., "Ethnic and racial differences in the presence of idiopathic pulmonary fibrosis at death," Respiratory Medicine, vol. 106, no. 4, pp. 588-593, 2012.

[6] L. M. Young, R. Hopkins, and M. L. Wilsher, "Lower occurrence of idiopathic pulmonary fibrosis in maori and pacific islanders," Respirology, vol. 11, no. 4, pp. 467-470, 2006.

[7] P. P. Bonanni, J. W. Frymoyer, and R. F. Jacox, "A family study of idiopathic pulmonary fibrosis. A possible dysproteinemic and genetically determined disease," The American Journal of Medicine, vol. 39, no. 3, pp. 411-421, 1965.

[8] P. Swaye, H. S. Van Ordstrand, L. J. McCormack, and S. E. Wolpaw, "Familial hamman-rich syndrome. Report of eight cases," Chest, vol. 55, no. 1, pp. 7-12, 1969.

[9] M. Schou, A. Amdisen, S. Eskjaer Jensen, and T. Olsen, "Occurrence of goitre during lithium treatment," The British Medical Journal, vol. 3, no. 5620, pp. 710-713, 1968.

[10] C. H. M. van Moorsel, M. F. M. van Oosterhout, N. P. Barlo et al., "Surfactant protein $\mathrm{C}$ mutations are the basis of a significant portion of adult familial pulmonary fibrosis in a dutch cohort," American Journal of Respiratory and Critical Care Medicine, vol. 182, no. 11, pp. 1419-1425, 2010.

[11] J. E. Loyd, "Pulmonary fibrosis in families," American Journal of Respiratory Cell and Molecular Biology, vol. 29, no. 3, supplement, pp. S47-S50, 2003.

[12] C. García-Sancho, I. Buendía-Roldán, M. R. Fernández-Plata et al., "Familial pulmonary fibrosis is the strongest risk factor for 
idiopathic pulmonary fibrosis," Respiratory Medicine, vol. 105, no. 12, pp. 1902-1907, 2011.

[13] M. B. Scholand, H. Coon, R. Wolff, and L. Cannon-Albright, "Use of a genealogical database demonstrates heritability of pulmonary fibrosis," Lung, vol. 191, no. 5, pp. 475-481, 2013.

[14] L. M. Nogee, A. E. Dunbar, S. E. Wert, F. Askin, A. Hamvas, and J. A. Whitsett, "A mutation in the surfactant protein C gene associated with familial interstitial lung disease," The New England Journal of Medicine, vol. 344, no. 8, pp. 573-579, 2001.

[15] S. Ono, T. Tanaka, M. Ishida et al., "Surfactant protein C G100S mutation causes familial pulmonary fibrosis in Japanese kindred," European Respiratory Journal, vol. 38, no. 4, pp. 861869, 2011.

[16] A. Q. Thomas, K. Lane, J. Phillips III et al., "Heterozygosity for a surfactant protein $\mathrm{C}$ gene mutation associated with usual interstitial pneumonitis and cellular nonspecific interstitial pneumonitis in one kindred," American Journal of Respiratory and Critical Care Medicine, vol. 165, no. 9, pp. 1322-1328, 2002.

[17] W. E. Lawson, S. W. Grant, V. Ambrosini et al., "Genetic mutations in surfactant protein $\mathrm{C}$ are a rare cause of sporadic cases of IPF," Thorax, vol. 59, no. 11, pp. 977-980, 2004.

[18] P. Markart, C. Ruppert, M. Wygrecka et al., "Surfactant protein C mutations in sporadic forms of idiopathic interstitial pneumonias," European Respiratory Journal, vol. 29, no. 1, pp. 134-137, 2007.

[19] A. Hamvas, L. M. Nogee, F. V. White et al., "Progressive lung disease and surfactant dysfunction with a deletion in surfactant protein C gene," American Journal of Respiratory Cell and Molecular Biology, vol. 30, no. 6, pp. 771-776, 2004.

[20] S. Mulugeta, J. M. Gray, K. L. Notarfrancesco et al., "Identification of LBM180, a lamellar body limiting membrane protein of alveolar type II cells, as the ABC transporter protein ABCA3," The Journal of Biological Chemistry, vol. 277, no. 25, pp. 2214722155, 2002.

[21] M. F. Beers and S. Mulugeta, "Surfactant protein C biosynthesis and its emerging role in conformational lung disease," Annual Review of Physiology, vol. 67, pp. 663-696, 2005.

[22] J. A. Kropski, W. E. Lawson, L. R. Young, and T. S. Blackwell, "Genetic studies provide clues on the pathogenesis of idiopathic pulmonary fibrosis," Disease Models and Mechanisms, vol. 6, no. 1, pp. 9-17, 2013.

[23] W. E. Lawson, P. F. Crossno, V. V. Polosukhin et al., "Endoplasmic reticulum stress in alveolar epithelial cells is prominent in IPF: association with altered surfactant protein processing and herpesvirus infection," American Journal of Physiology-Lung Cellular and Molecular Physiology, vol. 294, no. 6, pp. L1119L1126, 2008.

[24] H. Tanjore, D.-S. Cheng, A. L. Degryse et al., "Alveolar epithelial cells undergo epithelial-to-mesenchymal transition in response to endoplasmic reticulum stress," The Journal of Biological Chemistry, vol. 286, no. 35, pp. 30972-30980, 2011.

[25] S. Mulugeta, J. A. Maguire, J. L. Newitt, S. J. Russo, A. Kotorashvili, and M. F. Beers, "Misfolded BRICHOS SPC mutant proteins induce apoptosis via caspase-4- and cytochrome c-related mechanisms," The American Journal of Physiology-Lung Cellular and Molecular Physiology, vol. 293, no. 3, pp. L720-L729, 2007.

[26] B. D. Uhal and H. Nguyen, "The witschi hypothesis revisited after 35 years: genetic proof from SP-C BRICHOS domain mutations," The American Journal of Physiology-Lung Cellular and Molecular Physiology, vol. 305, no. 12, pp. L906-L911, 2013.
[27] M. Korfei, C. Ruppert, P. Mahavadi et al., "Epithelial endoplasmic reticulum stress and apoptosis in sporadic idiopathic pulmonary fibrosis," American Journal of Respiratory and Critical Care Medicine, vol. 178, no. 8, pp. 838-846, 2008.

[28] H. S. Cameron, M. Somaschini, P. Carrera et al., "A common mutation in the surfactant protein $\mathrm{C}$ gene associated with lung disease," The Journal of Pediatrics, vol. 146, no. 3, pp. 370-375, 2005.

[29] M. F. Beers, A. Hawkins, J. A. Maguire et al., "A nonaggregating surfactant protein $\mathrm{C}$ mutant is misdirected to early endosomes and disrupts phospholipid recycling," Traffic, vol. 12, no. 9, pp. 1196-1210, 2011.

[30] A. Hawkins, S. H. Guttentag, R. Deterding et al., "A nonBRICHOS SFTPC mutant (SP-CI73T) linked to interstitial lung disease promotes a late block in macroautophagy disrupting cellular proteostasis and mitophagy," American Journal of Physiology-Lung Cellular and Molecular Physiology, vol. 308, no. 1, pp. L33-L47, 2015.

[31] M. Woischnik, C. Sparr, S. Kern et al., "A non-BRICHOS surfactant protein $\mathrm{c}$ mutation disrupts epithelial cell function and intercellular signaling," BMC Cell Biology, vol. 11, article 88, 2010.

[32] Y. Wang, P. J. Kuan, C. Xing et al., "Genetic defects in surfactant protein A2 are associated with pulmonary fibrosis and lung cancer," American Journal of Human Genetics, vol. 84, no. 1, pp. 52-59, 2009.

[33] J. Madsen, I. Tornøe, O. Nielsen, C. Koch, W. Steinhilber, and U. Holmskov, "Expression and localization of lung surfactant protein A in human tissues," American Journal of Respiratory Cell and Molecular Biology, vol. 29, no. 5, pp. 591-597, 2003.

[34] J. Floros, G. Wang, and A. N. Mikerov, "Genetic complexity of the human innate host defense molecules, surfactant protein A1 (SP-A1) and SP-A2-impact on function," Critical Reviews in Eukaryotic Gene Expression, vol. 19, no. 2, pp. 125-137, 2009.

[35] M. Maitra, Y. Wang, R. D. Gerard, C. R. Mendelson, and C. K. Garcia, "Surfactant protein A2 mutations associated with pulmonary fibrosis lead to protein instability and endoplasmic reticulum stress," The Journal of Biological Chemistry, vol. 285, no. 29, pp. 22103-22113, 2010.

[36] B. Zhu, C. H. Ferry, L. K. Markell et al., “The nuclear receptor peroxisome proliferator-activated receptor- $\beta / \delta$ (PPAR $\beta / \delta)$ promotes oncogene-induced cellular senescence through repression of endoplasmic reticulum stress," Journal of Biological Chemistry, vol. 289, no. 29, pp. 20102-20119, 2014.

[37] S. A. Yousem and M. B. Beasley, "Bronchioloalveolar carcinoma: a review of current concepts and evolving issues," Archives of Pathology and Laboratory Medicine, vol. 131, no. 7, pp. 1027-1032, 2007.

[38] S. Shulenin, L. M. Nogee, T. Annilo, S. E. Wert, J. A. Whitsett, and M. Dean, "ABCA3 gene mutations in newborns with fatal surfactant deficiency," The New England Journal of Medicine, vol. 350, no. 13, pp. 1296-1303, 2004.

[39] F. Flamein, L. Riffault, C. Muselet-Charlier et al., "Molecular and cellular characteristics of ABCA3 mutations associated with diffuse parenchymal lung diseases in children," Human Molecular Genetics, vol. 21, no. 4, pp. 765-775, 2012.

[40] G. H. Deutsch, L. R. Young, R. R. Deterding et al., "Diffuse lung disease in young children: application of a novel classification scheme," American Journal of Respiratory and Critical Care Medicine, vol. 176, no. 11, pp. 1120-1128, 2007. 
[41] N. Cheong, M. Madesh, L. W. Gonzales et al., "Functional and trafficking defects in ATP binding cassette $\mathrm{A}_{3}$ mutants associated with respiratory distress syndrome," Journal of Biological Chemistry, vol. 281, no. 14, pp. 9791-9800, 2006.

[42] Y. Matsumura, N. Ban, K. Ueda, and N. Inagaki, "Characterization and classification of ATP-binding cassette transporter ABCA3 mutants in fatal surfactant deficiency," Journal of Biological Chemistry, vol. 281, no. 45, pp. 34503-34514, 2006.

[43] Y. Matsumura, N. Ban, and N. Inagaki, "Aberrant catalytic cycle and impaired lipid transport into intracellular vesicles in ABCA3 mutants associated with nonfatal pediatric interstitial lung disease," The American Journal of Physiology: Lung Cellular and Molecular Physiology, vol. 295, no. 4, pp. L698-L707, 2008.

[44] N. Weichert, E. Kaltenborn, A. Hector et al., "Some ABCA3 mutations elevate ER stress and initiate apoptosis of lung epithelial cells," Respiratory Research, vol. 12, article 4, 2011.

[45] I. Campo, M. Zorzetto, F. Mariani et al., "A large kindred of pulmonary fibrosis associated with a novel ABCA3 gene variant," Respiratory Research, vol. 15, article 43, 2014.

[46] R. Epaud, C. Delestrain, M. Louha, S. Simon, P. Fanen, and A. Tazi, "Combined pulmonary fibrosis and emphysema syndrome associated with ABCA3 mutations," European Respiratory Journal, vol. 43, no. 2, pp. 638-641, 2014.

[47] V. Cottin, H. Nunes, P.-Y. Brillet et al., "Combined pulmonary fibrosis and emphysema: a distinct underrecognised entity," European Respiratory Journal, vol. 26, no. 4, pp. 586-593, 2005.

[48] M. Brantly, N. A. Avila, V. Shotelersuk, C. Lucero, M. Huizing, and W. A. Gahl, "Pulmonary function and high-resolution CT findings in patients with an inherited form of pulmonary fibrosis, Hermansky-Pudlak syndrome, due to mutations in HPS-1," Chest, vol. 117, no. 1, pp. 129-136, 2000.

[49] C. Carmona-Rivera, D. R. Simeonov, N. D. Cardillo, W. A. Gahl, and C. L. Cadilla, "A divalent interaction between HPS1 and HPS4 is required for the formation of the biogenesis of lysosome-related organelle complex-3 (BLOC-3)," Biochimica et Biophysica Acta, vol. 1833, no. 3, pp. 468-478, 2013.

[50] S. M. Casalino-Matsuda, M. E. Monzon, A. J. Day, and R. M. Forteza, "Hyaluronan fragments/CD44 mediate oxidative stress-induced MUC5B up-regulation in airway epithelium," The American Journal of Respiratory Cell and Molecular Biology, vol. 40, no. 3, pp. 277-285, 2009.

[51] A.-H. Wei and W. Li, "Hermansky-Pudlak syndrome: pigmentary and non-pigmentary defects and their pathogenesis," Pigment Cell and Melanoma Research, vol. 26, no. 2, pp. 176-192, 2013.

[52] D. M. Pierson, D. Ionescu, G. Qing et al., "Pulmonary fibrosis in Hermansky-Pudlak syndrome: a case report and review," Respiration, vol. 73, no. 3, pp. 382-395, 2006.

[53] K. Furuhashi, N. Enomoto, T. Fujisawa et al., "HermanskyPudlak syndrome with nonspecific interstitial pneumonia," Internal Medicine, vol. 53, no. 5, pp. 449-453, 2014.

[54] J. J. van der Vis, L. ten Klooster, M. F. M. van Oosterhout, J. C. Grutters, and C. H. M. van Moorsel, "The occurrence of hermansky pudlak syndrome in patients with idiopathic pulmonary fibrosis-a cohort study," Journal of Genetic Syndromes \& Gene Therapy, vol. 4, article 141, 2013.

[55] M. Y. Armanios, J. J.-L. Chen, J. D. Cogan et al., “Telomerase mutations in families with idiopathic pulmonary fibrosis," The New England Journal of Medicine, vol. 356, no. 13, pp. 1317-1326, 2007.
[56] K. D. Tsakiri, J. T. Cronkhite, P. J. Kuan et al., "Adult-onset pulmonary fibrosis caused by mutations in telomerase," Proceedings of the National Academy of Sciences of the United States of America, vol. 104, no. 18, pp. 7552-7557, 2007.

[57] M. Armanios, "Telomeres and age-related disease: how telomere biology informs clinical paradigms," The Journal of Clinical Investigation, vol. 123, no. 3, pp. 996-1002, 2013.

[58] A. J. Zaug, S. M. Crary, M. J. Fioravanti, K. Campbell, and T. R. Cech, "Many disease-associated variants of hTERT retain high telomerase enzymatic activity," Nucleic Acids Research, vol. 41, no. 19, pp. 8969-8978, 2013.

[59] T. Vulliamy, A. Marrone, R. Szydlo, A. Walne, P. J. Mason, and I. Dokal, "Disease anticipation is associated with progressive telomere shortening in families with dyskeratosis congenita due to mutations in TERC," Nature Genetics, vol. 36, no. 5, pp. 447449, 2004.

[60] J. T. Cronkhite, C. Xing, G. Raghu et al., “Telomere shortening in familial and sporadic pulmonary fibrosis," American Journal of Respiratory and Critical Care Medicine, vol. 178, no. 7, pp. 729737, 2008.

[61] J. K. Alder, J. J.-L. Chen, L. Lancaster et al., "Short telomeres are a risk factor for idiopathic pulmonary fibrosis," Proceedings of the National Academy of Sciences of the United States of America, vol. 105, no. 35, pp. 13051-13056, 2008.

[62] R. Snetselaar, C. H. van Moorsel, K. M. Kazemier et al., "Telomere length in interstitial lung diseases," Chest, 2015.

[63] J. K. Alder, S. E. Stanley, C. L. Wagner, M. Hamilton, V. S. Hanumanthu, and M. Armanios, "Exome sequencing identifies mutant TINF2 in a family with pulmonary fibrosis," Chest, vol. 147, no. 5, pp. 1361-1368, 2015.

[64] J. A. Kropski, D. B. Mitchell, C. Markin et al., "A novel dyskerin (DKC1) mutation is associated with familial interstitial pneumonia," Chest, vol. 146, no. 1, pp. e1-e7, 2014.

[65] J. D. Cogan, J. A. Kropski, M. Zhao et al., "Rare variants in RTEL1 are associated with familial interstitial pneumonia," American Journal of Respiratory and Critical Care Medicine, vol. 191, no. 6, pp. 646-655, 2015.

[66] C. Kannengiesser, R. Borie, C. Menard et al., "Heterozygous RTEL1 mutations are associated with familial pulmonary fibrosis," European Respiratory Journal, vol. 46, no. 2, pp. 474-485, 2015.

[67] B. D. Stuart, J. Choi, S. Zaidi et al., "Exome sequencing links mutations in PARN and RTEL1 with familial pulmonary fibrosis and telomere shortening," Nature Genetics, vol. 47, no. 5, pp. 512-517, 2015.

[68] C. E. Barkauskas, M. J. Cronce, C. R. Rackley et al., “Type 2 alveolar cells are stem cells in adult lung," The Journal of Clinical Investigation, vol. 123, no. 7, pp. 3025-3036, 2013.

[69] D. Warburton, L. Perin, R. Defilippo, S. Bellusci, W. Shi, and B. Driscoll, "Stem/progenitor cells in lung development, injury repair, and regeneration," Proceedings of the American Thoracic Society, vol. 5, no. 6, pp. 703-706, 2008.

[70] J. K. Alder, C. E. Barkauskas, N. Limjunyawong et al., “Telomere dysfunction causes alveolar stem cell failure," Proceedings of the National Academy of Sciences of the United States of America, vol. 112, no. 16, pp. 5099-5104, 2015.

[71] M. Plataki, A. V. Koutsopoulos, K. Darivianaki, G. Delides, N. M. Siafakas, and D. Bouros, "Expression of apoptotic and antiapoptotic markers in epithelial cells in idiopathic pulmonary fibrosis," Chest, vol. 127, no. 1, pp. 266-274, 2005. 
[72] N. M. Korthagen, C. H. M. van Moorsel, N. P. Barlo, K. M. Kazemier, H. J. T. Ruven, and J. C. Grutters, "Association between variations in cell cycle genes and idiopathic pulmonary fibrosis," PLoS ONE, vol. 7, no. 1, Article ID e30442, 2012.

[73] J. C. Grutters and R. M. du Bois, "Genetics of fibrosing lung diseases," European Respiratory Journal, vol. 25, no. 5, pp. 915927, 2005.

[74] N. P. Barlo, C. H. M. van Moorsel, N. M. Korthagen et al., "Genetic variability in the IL1RN gene and the balance between interleukin (IL)-1 receptor agonist and IL-1beta in idiopathic pulmonary fibrosis," Clinical and Experimental Immunology, vol. 166, no. 3, pp. 346-351, 2011.

[75] R. L. Riha, I. A. Yang, G. C. Rabnott, A. M. Tunnicliffe, K. M. Fong, and P. V. Zimmerman, "Cytokine gene polymorphisms in idiopathic pulmonary fibrosis," Internal Medicine Journal, vol. 34, no. 3, pp. 126-129, 2004.

[76] M. Whyte, R. Hubbard, R. Meliconi et al., "Increased risk of fibrosing alveolitis associated with interleukin-1 receptor antagonist and tumor necrosis factor- $\alpha$ gene polymorphisms," The American Journal of Respiratory and Critical Care Medicine, vol. 162, no. 2, pp. 755-758, 2000.

[77] B. Hutyrova, P. Pantelidis, J. Drabek et al., "Interleukin-1 gene cluster polymorphisms in sarcoidosis and idiopathic pulmonary fibrosis," American Journal of Respiratory and Critical Care Medicine, vol. 165, no. 2, pp. 148-151, 2002.

[78] N. M. Korthagen, C. H. M. van Moorsel, K. M. Kazemier, H. J. T. Ruven, and J. C. Grutters, "ILIRN genetic variations and risk of IPF: a meta-analysis and mRNA expression study," Immunogenetics, vol. 64, no. 5, pp. 371-377, 2012.

[79] P. Gasse, C. Mary, I. Guenon et al., "IL-1R1/MyD88 signaling and the inflammasome are essential in pulmonary inflammation and fibrosis in mice," The Journal of Clinical Investigation, vol. 117, no. 12, pp. 3786-3799, 2007.

[80] I. Aksentijevich, S. L. Masters, P. J. Ferguson et al., "An autoinflammatory disease with deficiency of the interleukin-1receptor antagonist," The New England Journal of Medicine, vol. 360, no. 23, pp. 2426-2437, 2009.

[81] E. Arzt, J. Sauer, T. Pollmächer et al., "Glucocorticoids suppress interleukin-1 receptor antagonist synthesis following induction by endotoxin," Endocrinology, vol. 134, no. 2, pp. 672-677, 1994.

[82] G. Raghu, K. J. Anstrom, T. E. King Jr., J. A. Lasky, and F. J. Martinez, "Prednisone, azathioprine, and $N$-acetylcysteine for pulmonary fibrosis," The New England Journal of Medicine, vol. 366, no. 21, pp. 1968-1977, 2012.

[83] M. A. Seibold, A. L. Wise, M. C. Speer et al., "A common MUC5B promoter polymorphism and pulmonary fibrosis," The New England Journal of Medicine, vol. 364, no. 16, pp. 1503-1512, 2011.

[84] Y. Zhang, I. Noth, J. G. N. Garcia, and N. Kaminski, "A variant in the promoter of MUC5B and idiopathic pulmonary fibrosis," The New England Journal of Medicine, vol. 364, no. 16, pp. 15761577, 2011.

[85] W. Bodmer and C. Bonilla, "Common and rare variants in multifactorial susceptibility to common diseases," Nature Genetics, vol. 40, no. 6, pp. 695-701, 2008.

[86] A. L. Peljto, M. Selman, D. S. Kim et al., “The MUC5B promoter polymorphism is associated with idiopathic pulmonary fibrosis in a Mexican cohort but is rare among Asian ancestries," Chest, vol. 147, no. 2, pp. 460-464, 2015.

[87] Y. Horimasu, S. Ohshimo, F. Bonella et al., "MUC5B promoter polymorphism in Japanese patients with idiopathic pulmonary fibrosis," Respirology, vol. 20, no. 3, pp. 439-444, 2015.
[88] M. A. Seibold, R. W. Smith, C. Urbanek et al., "The idiopathic pulmonary fibrosis honeycomb cyst contains a mucocilary pseudostratified epithelium," PLoS ONE, vol. 8, no. 3, Article ID e58658, 2013.

[89] Y. Chen, Y. H. Zhao, Y.-P. Di, and R. Wu, "Characterization of human mucin $5 \mathrm{~B}$ gene expression in airway epithelium and the genomic clone of the amino-terminal and $5^{\prime}$-flanking region," American Journal of Respiratory Cell and Molecular Biology, vol. 25 , no. 5, pp. 542-553, 2001.

[90] M. C. Rose and J. A. Voynow, "Respiratory tract mucin genes and mucin glycoproteins in health and disease," Physiological Reviews, vol. 86, no. 1, pp. 245-278, 2006.

[91] T. Fujisawa, M. M.-J. Chang, S. Velichko et al., "NF- $\kappa$ B mediates IL-1 $\beta$ - and IL-17A-induced MUC5B expression in airway epithelial cells," The American Journal of Respiratory Cell and Molecular Biology, vol. 45, no. 2, pp. 246-252, 2011.

[92] G. P. Cosgrove, S. D. Groshong, A. L. Peljto et al., "The MUC5B promoter polymorphism is associated with a less severe pathological form of familial interstitial pneumonia (FIP)," American Journal of Respiratory and Critical Care Medicine, vol. 185, Article ID A6865, 2012.

[93] M. G. Roy, A. Livraghi-Butrico, A. A. Fletcher et al., "Muc5b is required for airway defence," Nature, vol. 505, no. 7483, pp. 412-416, 2014.

[94] P. L. Molyneaux, M. J. Cox, S. A. G. Willis-Owen et al., "The role of bacteria in the pathogenesis and progression of idiopathic pulmonary fibrosis," American Journal of Respiratory and Critical Care Medicine, vol. 190, no. 8, pp. 906-913, 2014.

[95] A. L. Peljto, Y. Zhang, T. E. Fingerlin et al., "Association between the MUC5B promoter polymorphism and survival in patients with idiopathic pulmonary fibrosis," Journal of the American Medical Association, vol. 309, no. 21, pp. 2232-2239, 2013.

[96] C. J. Stock, H. Sato, C. Fonseca et al., "Mucin 5B promoter polymorphism is associated with idiopathic pulmonary fibrosis but not with development of lung fibrosis in systemic sclerosis or sarcoidosis," Thorax, vol. 68, no. 5, pp. 436-441, 2013.

[97] T. Mushiroda, S. Wattanapokayakit, A. Takahashi et al., "A genome-wide association study identifies an association of a common variant in TERT with susceptibility to idiopathic pulmonary fibrosis," Journal of Medical Genetics, vol. 45, no. 10, pp. 654-656, 2008.

[98] T. E. Fingerlin, E. Murphy, W. Zhang et al., "Genome-wide association study identifies multiple susceptibility loci for pulmonary fibrosis," Nature Genetics, vol. 45, no. 6, pp. 613-620, 2013.

[99] H. Corvol, C. A. Hodges, M. L. Drumm, and L. Guillot, "Moving beyond genetics: is FAM13A a major biological contributor in lung physiology and chronic lung diseases?" Journal of Medical Genetics, vol. 51, no. 10, pp. 646-649, 2014.

[100] I. Noth, Y. Zhang, S.-F. Ma et al., "Genetic variants associated with idiopathic pulmonary fibrosis susceptibility and mortality: a genome-wide association study," The Lancet Respiratory Medicine, vol. 1, no. 4, pp. 309-317, 2013.

[101] D. E. Reich, M. Cargili, S. Boik et al., "Linkage disequilibrium in the human genome," Nature, vol. 411, no. 6834, pp. 199-204, 2001.

[102] W. Y. S. Wang, B. J. Barratt, D. G. Clayton, and J. A. Todd, "Genome-wide association studies: theoretical and practical concerns," Nature Reviews Genetics, vol. 6, no. 2, pp. 109-118, 2005.

[103] G. M. Hunninghake, H. Hatabu, Y. Okajima et al., "MUC5B promoter polymorphism and interstitial lung abnormalities," 
The New England Journal of Medicine, vol. 368, no. 23, pp. 21922200, 2013.

[104] K. O. Leslie, "Idiopathic pulmonary fibrosis may be a disease of recurrent, tractional injury to the periphery of the aging lung: a unifying hypothesis regarding etiology and pathogenesis," Archives of Pathology and Laboratory Medicine, vol. 136, no. 6, pp. 591-600, 2012.

[105] A. Carloni, V. Poletti, L. Fermo, N. Bellomo, and M. Chilosi, "Heterogeneous distribution of mechanical stress in human lung: a mathematical approach to evaluate abnormal remodeling in IPF,' Journal of Theoretical Biology, vol. 332, pp. 136-140, 2013.

[106] D. Shier, J. Butler, and R. Lewis, "Respiratory system," in Hole's Human Anatomy and Physiology, chapter 19, pp. 752-790, McGraw-Hill, 11th edition, 2007.

[107] J. A. Whitsett, S. E. Wert, and T. E. Weaver, "Alveolar surfactant homeostasis and the pathogenesis of pulmonary disease," Annual Review of Medicine, vol. 61, pp. 105-119, 2010.

[108] R. Zarbock, M. Woischnik, C. Sparr et al., "The surfactant protein C mutation A116D alters cellular processing, stress tolerance, surfactant lipid composition, and immune cell activation," BMC Pulmonary Medicine, vol. 12, article 15, 2012.

[109] J. A. Maguire, S. Mulugeta, and M. F. Beers, "Endoplasmic reticulum stress induced by surfactant protein $\mathrm{C}$ BRICHOS mutants promotes proinflammatory signaling by epithelial cells," American Journal of Respiratory Cell and Molecular Biology, vol. 44, no. 3, pp. 404-414, 2011.

[110] S. Mulugeta, V. Nguyen, S. J. Russo, M. Muniswamy, and M. F. Beers, "A surfactant protein C precursor protein BRICHOS domain mutation causes endoplasmic reticulum stress, proteasome dysfunction, and caspase 3 activation," American Journal of Respiratory Cell and Molecular Biology, vol. 32, no. 6, pp. 521530, 2005.

[111] J. A. Maguire, S. Mulugeta, and M. F. Beers, "Multiple ways to die: delineation of the unfolded protein response and apoptosis induced by surfactant protein C BRICHOS mutants," International Journal of Biochemistry and Cell Biology, vol. 44, no. 1, pp. 101-112, 2012.

[112] T. Thurm, E. Kaltenborn, S. Kern, M. Griese, and R. Zarbock, "SFTPC mutations cause SP-C degradation and aggregate formation without increasing ER stress," European Journal of Clinical Investigation, vol. 43, no. 8, pp. 791-800, 2013.

[113] K. R. Khubchandani, K. L. Goss, J. F. Engelhardt, and J. M. Snyder, "In situ hybridization of SP-A mRNA in adult human conducting airways," Pediatric Pathology and Molecular Medicine, vol. 20, no. 5, pp. 349-366, 2001.

[114] H. Saitoh, H. Okayama, S. Shimura, T. Fushimi, T. Masuda, and K. Shirato, "Surfactant protein A2 gene expression by human airway submucosal gland cells," American Journal of Respiratory Cell and Molecular Biology, vol. 19, no. 2, pp. 202-209, 1998.

[115] M. J. Tino and J. R. Wright, "Interactions of surfactant protein A with epithelial cells and phagocytes," Biochimica et Biophysica Acta-Molecular Basis of Disease, vol. 1408, no. 2-3, pp. 241-263, 1998.

[116] C. J. Wong, J. Akiyama, L. Allen, and S. Hawgood, "Localization and developmental expression of surfactant proteins D and A in the respiratory tract of the mouse," Pediatric Research, vol. 39, no. 6, pp. 930-937, 1996.

[117] A. M. Pastva, J. R. Wright, and K. L. Williams, "Immunomodulatory roles of surfactant proteins A and D: implications in lung disease," Proceedings of the American Thoracic Society, vol. 4, no. 3, pp. 252-257, 2007.
[118] Y. Wang, P. J. Kuan, C. Xing et al., "Genetic defects in surfactant protein A2 are associated with pulmonary fibrosis and lung cancer," The American Journal of Human Genetics, vol. 84, no. 1, pp. 52-59, 2009.

[119] Y. Song, G. Fang, H. Shen et al., "Human surfactant protein A2 gene mutations impair dimmer/trimer assembly leading to deficiency in protein sialylation and secretion," PLOS ONE, vol. 7, no. 10, Article ID e46559, 2012.

[120] G. Yamano, H. Funahashi, O. Kawanami et al., "ABCA3 is a lamellar body membrane protein in human lung alveolar type II cells," FEBS Letters, vol. 508, no. 2, pp. 221-225, 2001.

[121] E. Bruder, J. Hofmeister, C. Aslanidis et al., "Ultrastructural and molecular analysis in fatal neonatal interstitial pneumonia caused by a novel ABCA3 mutation," Modern Pathology, vol. 20, no. 10, pp. 1009-1018, 2007.

[122] T. H. Garmany, M. A. Moxley, F. V. White et al., "Surfactant composition and function in patients with ABCA3 mutations," Pediatric Research, vol. 59, no. 6, pp. 801-805, 2006.

[123] B. Driscoll, S. Buckley, K. C. Bui, K. D. Anderson, and D. Warburton, "Telomerase in alveolar epithelial development and repair," The American Journal of Physiology-Lung Cellular and Molecular Physiology, vol. 279, no. 6, pp. L1191-L1198, 2000.

[124] T. Liu, M. Ullenbruch, Y. Y. Choi et al., "Telomerase and telomere length in pulmonary fibrosis," American Journal of Respiratory Cell and Molecular Biology, vol. 49, no. 2, pp. 260268, 2013.

[125] Y. Nozaki, T. Liu, K. Hatano, M. Gharaee-Kermani, and S. H. Phan, "Induction of telomerase activity in fibroblasts from bleomycin-injured lungs," American Journal of Respiratory Cell and Molecular Biology, vol. 23, no. 4, pp. 460-465, 2000.

[126] Z. G. Fridlender, P. Y. Cohen, O. Golan, N. Arish, S. WallachDayan, and R. Breuer, "Telomerase activity in bleomycininduced epithelial cell apoptosis and lung fibrosis," European Respiratory Journal, vol. 30, no. 2, pp. 205-213, 2007.

[127] C. W. Greider and E. H. Blackburn, "Identification of a specific telomere terminal transferase activity in tetrahymena extracts," Cell, vol. 43, no. 2, part 1, pp. 405-413, 1985.

[128] J.-L. Chen and C. W. Greider, "Telomerase RNA structure and function: implications for dyskeratosis congenita," Trends in Biochemical Sciences, vol. 29, no. 4, pp. 183-192, 2004.

[129] C. W. Greider and E. H. Blackburn, “The telomere terminal transferase of tetrahymena is a ribonucleoprotein enzyme with two kinds of primer specificity," Cell, vol. 51, no. 6, pp. 887-898, 1987.

[130] C. W. Greider and E. H. Blackburn, "A telomeric sequence in the RNA of Tetrahymena telomerase required for telomere repeat synthesis," Nature, vol. 337, no. 6205, pp. 331-337, 1989.

[131] A. Diaz de Leon, J. T. Cronkhite, A.-L. A. Katzenstein et al., "Telomere lengths, pulmonary fibrosis and telomerase (TERT) mutations," PLoS ONE, vol. 5, no. 5, Article ID e10680, 2010.

[132] J. M. Gansner, I. O. Rosas, and B. L. Ebert, "Pulmonary fibrosis, bone marrow failure, and telomerase mutation," The New England Journal of Medicine, vol. 366, no. 16, pp. 1551-1553, 2012.

[133] E. M. Parry, J. K. Alder, X. Qi, J. J.-L. Chen, and M. Armanios, "Syndrome complex of bone marrow failure and pulmonary fibrosis predicts germline defects in telomerase," Blood, vol. 117, no. 21, pp. 5607-5611, 2011.

[134] D. C. Chambers, B. E. Clarke, J. McGaughran, and C. K. Garcia, "Lung fibrosis, premature graying, and macrocytosis," American Journal of Respiratory and Critical Care Medicine, vol. 186, no. 5, pp. e8-e9, 2012. 
[135] R. T. Calado, J. A. Regal, D. E. Kleiner et al., "A spectrum of severe familial liver disorders associate with telomerase mutations," PLoS ONE, vol. 4, no. 11, Article ID e7926, 2009.

[136] M. Armanios, J.-L. Chen, Y.-P. C. Chang et al., "Haploinsufficiency of telomerase reverse transcriptase leads to anticipation in autosomal dominant dyskeratosis congenita," Proceedings of the National Academy of Sciences of the United States of America, vol. 102, no. 44, pp. 15960-15964, 2005.

[137] H.-Y. Du, R. Idol, S. Robledo et al., "Telomerase reverse transcriptase haploinsufficiency and telomere length in individuals with 5p- syndrome," Aging Cell, vol. 6, no. 5, pp. 689-697, 2007.

[138] C. K. Garcia, W. E. Wright, and J. W. Shay, "Human diseases of telomerase dysfunction: insights into tissue aging," Nucleic Acids Research, vol. 35, no. 22, pp. 7406-7416, 2007.

[139] J. K. Alder, N. Guo, F. Kembou et al., "Telomere length is a determinant of emphysema susceptibility," American Journal of Respiratory and Critical Care Medicine, vol. 184, no. 8, pp. 904912, 2011.

[140] S.-R. Jackson, J. Lee, R. Reddy et al., "Partial pneumonectomy of telomerase null mice carrying shortened telomeres initiates cell growth arrest resulting in a limited compensatory growth response," The American Journal of Physiology_Lung Cellular and Molecular Physiology, vol. 300, no. 6, pp. L898-L909, 2011.

[141] H. Ly, M. Schertzer, W. Jastaniah et al., "Identification and functional characterization of 2 variant alleles of the telomerase RNA template gene (TERC) in a patient with dyskeratosis congenita," Blood, vol. 106, no. 4, pp. 1246-1252, 2005.

[142] A. Marrone, P. Sokhal, A. Walne et al., "Functional characterization of novel telomerase RNA (TERC) mutations in patients with diverse clinical and pathological presentations," Haematologica, vol. 92, no. 8, pp. 1013-1020, 2007.

[143] F. Goldman, R. Bouarich, S. Kulkarni et al., "The effect of TERC haploinsufficiency on the inheritance of telomere length," Proceedings of the National Academy of Sciences of the United States of America, vol. 102, no. 47, pp. 17119-17124, 2005.

[144] T. Vulliamy, A. Marrone, F. Goldman et al., "The RNA component of telomerase is mutated in autosomal dominant dyskeratosis congenita," Nature, vol. 413, no. 6854, pp. 432-435, 2001.

[145] N. S. Heiss, S. W. Knight, T. J. Vulliamy et al., "X-linked dyskeratosis congenita is caused by mutations in a highly conserved gene with putative nucleolar functions," Nature Genetics, vol. 19, no. 1, pp. 32-38, 1998.

[146] J. K. Alder, E. M. Parry, S. Yegnasubramanian et al., “Telomere phenotypes in females with heterozygous mutations in the dyskeratosis congenita 1 (DKC1) gene," Human Mutation, vol. 34, no. 11, pp. 1481-1485, 2013.

[147] W. F. Safa, G. G. Lestringant, and P. M. Frossard, "X-linked dyskeratosis congenita: restrictive pulmonary disease and a novel mutation," Thorax, vol. 56, no. 11, pp. 891-894, 2001.

[148] S. Hisata, H. Sakaguchi, H. Kanegane et al., "A novel missense mutation of DKC1 in dyskeratosis congenita with pulmonary fibrosis," Sarcoidosis Vasculitis and Diffuse Lung Diseases, vol. 30, no. 3, pp. 221-225, 2013.

[149] L. A. Dvorak, R. Vassallo, S. Kirmani et al., "Pulmonary fibrosis in dyskeratosis congenita: report of 2 cases," Human Pathology, vol. 46, no. 1, pp. 147-152, 2014.

[150] S.-H. Kim, P. Kaminker, and J. Campisi, “TIN2, a new regulator of telomere length in human cells," Nature Genetics, vol. 23, no. 4, pp. 405-412, 1999.

[151] W. Palm and T. de Lange, "How shelterin protects mammalian telomeres," Annual Review of Genetics, vol. 42, pp. 301-334, 2008 .
[152] A. Fukuhara, Y. Tanino, T. Ishii et al., "Pulmonary fibrosis in dyskeratosis congenita with TINF2 gene mutation," European Respiratory Journal, vol. 42, no. 6, pp. 1757-1759, 2013.

[153] A. J. Walne, T. Vulliamy, R. Beswick, M. Kirwan, and I. Dokal, "TINF2 mutations result in very short telomeres: analysis of a large cohort of patients with dyskeratosis congenita and related bone marrow failure syndromes," Blood, vol. 112, no. 9, pp. 35943600, 2008.

[154] H. Ding, M. Schertzer, X. Wu et al., "Regulation of murine telomere length by Rtel: an essential gene encoding a helicaselike protein," Cell, vol. 117, no. 7, pp. 873-886, 2004.

[155] Z. Du, D. Zhao, Y. Zhao, S. Wang, Y. Gao, and N. Li, "Identification and characterization of bovine regulator of telomere length elongation helicase gene (RTEL): molecular cloning, expression distribution, splice variants and DNA methylation profile," BMC Molecular Biology, vol. 8, article 18, 2007.

[156] J.-B. Vannier, G. Sarek, and S. J. Boulton, "RTEL1: functions of a disease-associated helicase," Trends in Cell Biology, vol. 24, no. 7, pp. 416-425, 2014.

[157] Z. Deng, G. Glousker, A. Molczan et al., "Inherited mutations in the helicase RTEL1 cause telomere dysfunction and hoyeraalhreidarsson syndrome," Proceedings of the National Academy of Sciences of the United States of America, vol. 110, no. 36, pp. E3408-E3416, 2013.

[158] K. Buiting, C. Körner, B. Ulrich, E. Wahle, and B. Horsthemke, "The human gene for the poly(A)-specific ribonuclease (PARN) maps to $16 \mathrm{p} 13$ and has a truncated copy in the PraderWilli/Angelman syndrome region on $15 \mathrm{q} 11 \rightarrow \mathrm{q} 13$," Cytogenetics and Cell Genetics, vol. 87, no. 1-2, pp. 125-131, 1999.

[159] H. Tummala, A. Walne, L. Collopy et al., "Poly(A)-specific ribonuclease deficiency impacts telomere biology and causes dyskeratosis congenita," The Journal of Clinical Investigation, vol. 125, no. 5, pp. 2151-2160, 2015.

[160] Y. A. Bochkov, K. M. Hanson, S. Keles, R. A. BrockmanSchneider, N. N. Jarjour, and J. E. Gern, "Rhinovirus-induced modulation of gene expression in bronchial epithelial cells from subjects with asthma," Mucosal Immunology, vol. 3, no. 1, pp. 6980, 2010.

[161] L.-H. Pan, H. Ohtani, K. Yamauchi, and H. Nagura, "Coexpression of TNF $\alpha$ and IL- $\beta$ in human acute pulmonary fibrotic diseases: an immunohistochemical analysis," Pathology International, vol. 46, no. 2, pp. 91-99, 1996.

[162] L. Liu, A. A. Roberts, and T. Ganz, "By IL-1 signaling, monocytederived cells dramatically enhance the epidermal antimicrobial response to lipopolysaccharide," The Journal of Immunology, vol. 170, no. 1, pp. 575-580, 2003.

[163] S. Perrier, F. Darakhshan, and E. Hajduch, "IL-1 receptor antagonist in metabolic diseases: Dr Jekyll or Mr Hyde?" FEBS Letters, vol. 580, no. 27, pp. 6289-6294, 2006.

[164] R. Wei, C. Li, M. Zhang et al., "Association between MUC5B and TERT polymorphisms and different interstitial lung disease phenotypes," Translational Research, vol. 163, no. 5, pp. 494-502, 2014.

[165] D. J. Thornton, K. Rousseau, and M. A. McGuckin, "Structure and function of the polymeric mucins in airways mucus," Annual Review of Physiology, vol. 70, pp. 459-486, 2008.

[166] R. Sepper, K. Prikk, M. Metsis et al., "Mucin5B expression by lung alveolar macrophages is increased in long-term smokers," Journal of Leukocyte Biology, vol. 92, no. 2, pp. 319-324, 2012.

[167] R. Borie, B. Crestani, P. Dieude et al., "The MUC5B variant is associated with idiopathic pulmonary fibrosis but not with 
systemic sclerosis interstitial lung disease in the european caucasian population," PLoS ONE, vol. 8, no. 8, Article ID e70621, 2013.

[168] J. A. Kropski, J. M. Pritchett, D. F. Zoz et al., "Extensive phenotyping of individuals at risk for familial interstitial pneumonia reveals clues to the pathogenesis of interstitial lung disease," American Journal of Respiratory and Critical Care Medicine, vol. 191, no. 4, pp. 417-426, 2015.

[169] M. A. Coghlan, A. Shifren, H. J. Huang et al., "Sequencing of idiopathic pulmonary fibrosis-related genes reveals independent single gene associations," BMJ Open Respiratory Research, vol. 1, no. 1, Article ID e000057, 2014.

[170] S. Lührig, I. Siamishi, M. Tesmer-Wolf, U. Zechner, W. Engel, and J. Nolte, "Lrrc34, a novel nucleolar protein, interacts with $\mathrm{Npml}$ and Ncl and has an impact on pluripotent stem cells," Stem Cells and Development, vol. 23, no. 23, pp. 2862-2874, 2014. 


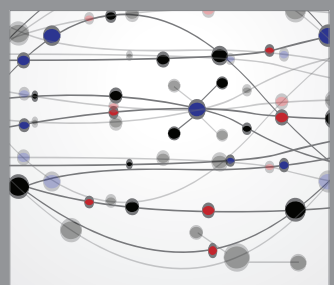

The Scientific World Journal
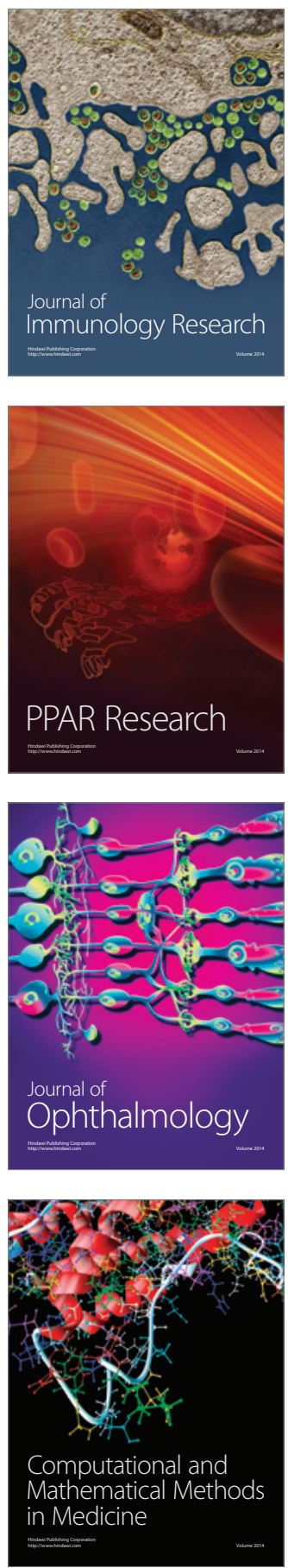

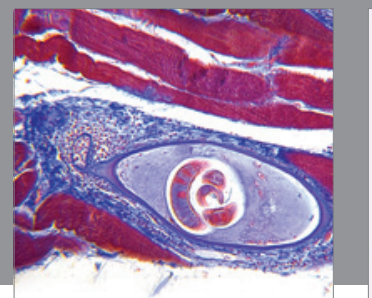

Gastroenterology

Research and Practice
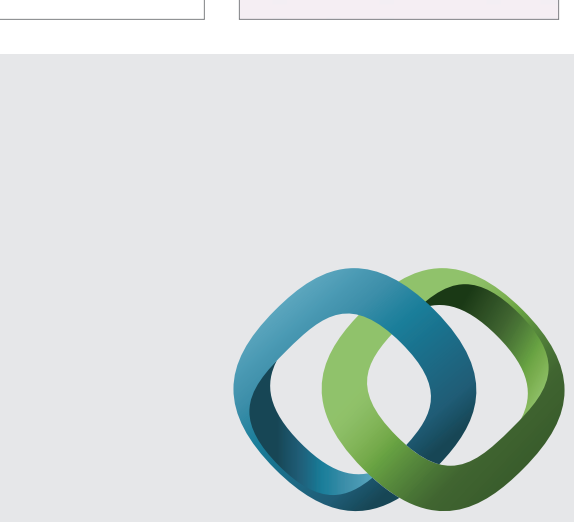

\section{Hindawi}

Submit your manuscripts at

http://www.hindawi.com
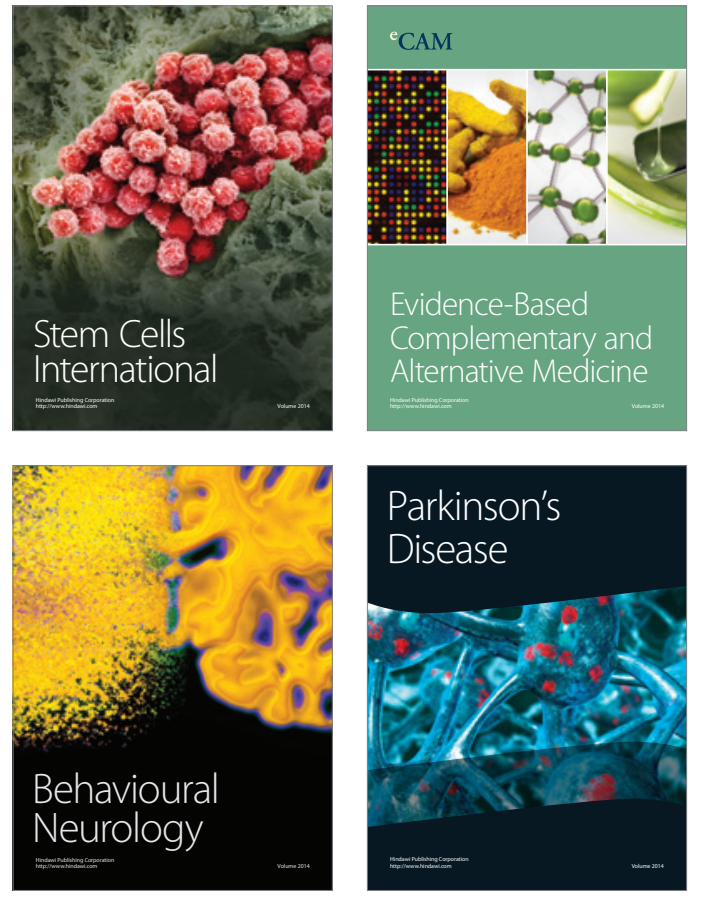
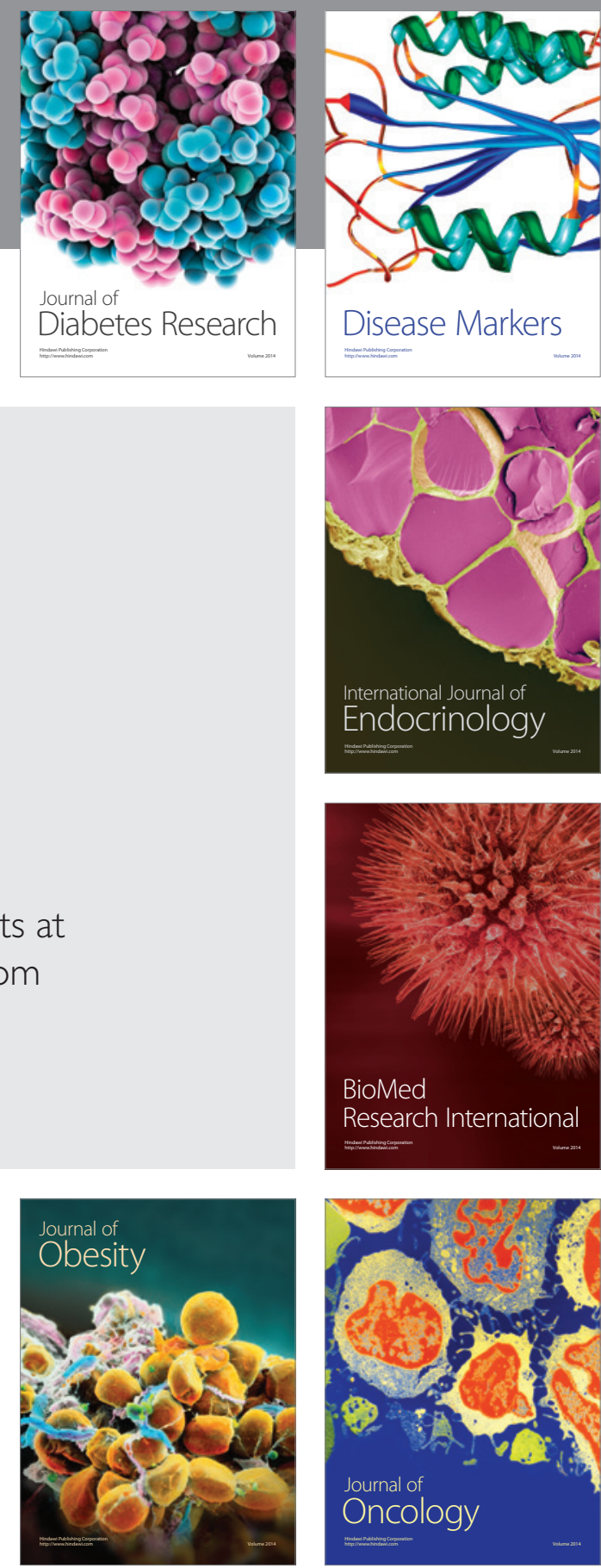

Disease Markers
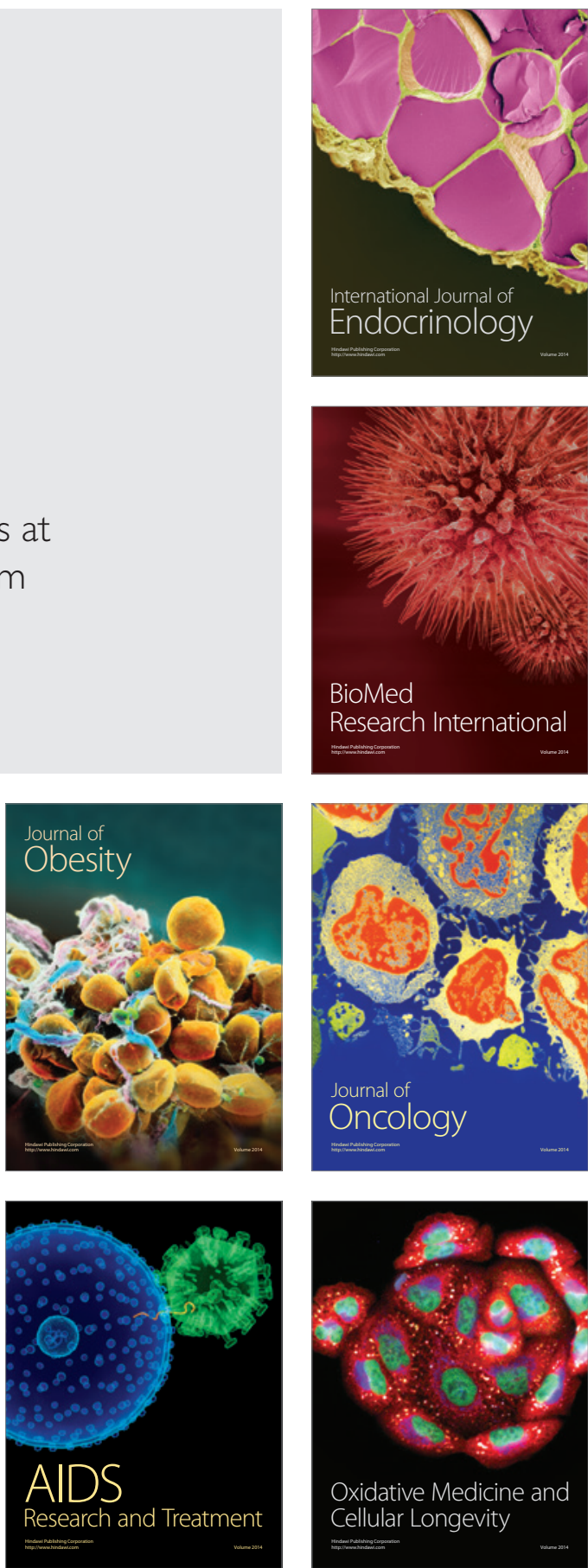